\title{
Shell preference of the hermit crab Pagurus exilis (Anomura: Paguridae) from Brazil and Argentina: a comparative study
}

\author{
Fernando L. Mantelatto ${ }^{1,2 *}$, Renata Biagi ${ }^{1}$, Andrea L. Meireles ${ }^{1,2}$ \& Marcelo A. Scelzo ${ }^{3}$ \\ 1 Laboratory of Bioecology and Crustacean Systematics, Department of Biology, Faculty of Philosophy, Sciences \\ and Letters of Ribeirão Preto (FFCLRP), University of São Paulo (USP), Av. Bandeirantes 3900, CEP 14040-901, \\ Ribeirão Preto, São Paulo, Brazil. \\ 2 Program of Post Graduation on Comparative Biology - FFCLRP/USP, Av. Bandeirantes 3900, CEP 14040-901, \\ Ribeirão Preto, São Paulo, Brazil. Fax: 55-16-36024396; flmantel@usp.br; renatabg@usp.br; andrealm@usp.br . \\ 3 Department of Marine Sciences, FCEyN, Mar del Plata Nacional University/CONICET. Funes 3350, (B7600AYL), \\ Mar del Plata, Argentina; mascelzo@mdp.edu.ar \\ * Correspondence author
}

Received 10-X-2005. C Corrected 08-VIII-2006. Accepted 16-III-2007.

\begin{abstract}
Shell preferences, as shown by laboratory choice experiments, are important determinants of shell utilization under natural conditions. Size and shell species preferences of the hermit crab Pagurus exilis were determined and compared for the most occupied shell types (Olivancillaria urceus, Natica isabelleana and Buccinanops gradatum) in the Caraguatatuba region, Brazil, and for the two most occupied species (B. gradatum and $N$. isabelleana) in Mar del Plata, Argentina. All experiments were conducted under laboratory conditions, using glass aquaria where the hermit crabs were placed naked with a large number of shells of appropriate sizes. After $36 \mathrm{~h}$ the crabs and chosen shells were measured. The relationship between preferred shell type, shell size and shell volume was determined by regression analysis. Pagurus exilis showed significant choices amongst shell types. Specimens from Argentina preferred N. isabelleana and those from Brazil chose B. gradatum > N. isabelleana $>\mathrm{O}$. urceus. Preferences were characterized by shell weight and internal volume. The present data lead us to conclude that shell selection by hermit crabs involves individual preferences related to the shell features that best provide protection and survival. Rev. Biol. Trop. 55 (Suppl. 1): 153-162. Epub 2007 June, 29.
\end{abstract}

Key words: Crustacea, Paguridae, Pagurus exilis, shell occupation, southwestern Atlantic.

Animals often must compromise among different sets of demands when selecting resources (Yoshino et al. 1999). In hermit crabs particularly, shell selection is not by chance but based on adequacy and availability of resources (Reese 1962, Conover 1978), and is affected by both shell size and species (Abrams 1978, Conover 1978, Blackstone 1985, Lively 1988, Siu and Lee 1992, Ohmori et al. 1995, Hahn 1998, Rodrigues et al. 2000, Mantelatto and Dominciano 2002, Mantelatto and Meireles 2004).

Moreover, the fitness of a particular shell may differ between hermit crab species, reflecting several selection pressures, which associated with different habitats, act in different ways on each crab species (Bertness 1981) in different areas. Although the shell selection process has been well investigated (Vance 1972, Elwood et al. 1979, Bertness 1980, Wilber 1990, Hazlett 1992, 1996, Ohmori et al. 1995, Wada et al. 1997, Garcia and Mantelatto 2001, Meireles and Mantelatto 2005), there is a scarcity of studies about the shell preferences of two different populations of the same species from different locations distantly removed from one another. Comparative studies of species known to occur over wide geographical 
ranges can provide valuable information on the development of intraspecific adaptations to different environmental conditions. Unfortunately, the number of studies conducted on this subject is too limited to permit an understanding of the life cycle strategies of the high number of described decapod crustaceans worldwide (FL Mantelatto pers. obs.).

According to Hendrickx and Harvey (1999), three groups of hermit crabs in particular (i.e., the genera Pagurus, Paguristes, and the "Pylopagurus-like" species) have been difficult to study because there are many stillundescribed species. Many species are known from one or a few localities, and many stillundescribed species are known to occur worldwide. The genus Pagurus Fabricius, 1775 is a heterogeneous pagurid group consisting of more than 170 species worldwide (Lemaitre and Cruz Castaño 2004), and ecological information for this genus is still scarce despite the easily accessible habitats it inhabits and its high abundance (Goshima et al. 1996).

Despite of a number of publications about the distribution of Pagurus exilis (Benedict, 1892) (Melo 1999), studies on the species have been limited to the post-embryonic development under laboratory conditions (Scelzo and Boschi 1969) and on distributional aspects and population structure in Brazilian waters (Terossi et al. 2006, Mantelatto et al. in press, respectively). Here we evaluated the shell size and species preference of two different biogeographical populations (Brazil and Argentina) of $P$. exilis under laboratory conditions, comparing the puzzling mechanisms of shell selection.

\section{MATERIALS AND METHODS}

Hermit crabs were collected in Caraguatatuba Bay (23 $47^{\circ} \mathrm{S}$ and $45^{\circ} 08^{\prime}$ W) (Brazil) during 2002 and in Mar del Plata and Mar Chiquita (38 $02^{\circ} \mathrm{S}$ and $57^{\circ} 31^{\prime} \mathrm{W}$ ) (Argentina) during 2003 by a fishing boat equipped with otter-trawl nets. Both study localities are approximately $5000 \mathrm{~km}$ separated from each other. The animals collected in Brazil were transported to the Laboratory of Bioecology and Crustacean Systematics at the Faculty of Philosophy, Sciences and Letters (FFCLRP), University of São Paulo (USP), Ribeirão Preto, São Paulo, Brazil; those collected in Argentina were taken to the Department of Marine Sciences, Faculty of Exact and Natural Sciences, Mar del Plata National University (UNMdP), Mar del Plata, Argentina, where experiments were conducted using glass aquaria provided with flowing sea water.

Laboratory experiments followed the methodology adopted by Garcia and Mantelatto (2001) in almost all aspects; each animal was utilized only once to avoid any acquired behavior and returned to the field in a different area from previous capture (except those who died in laboratory or used as voucher). In all experiments, hermit crabs were removed from their chosen shells by heating the apex of the shell in hot water. The data of animals that died during the experiments were not included in the analysis.

To determine correlations between characteristics of hermit crabs and their preferred shells, regression analyses were computed. The chi-square test $\left(\chi^{2}\right)$ was used to compare occupancy of shell species, and morphometric relationships were established by regression analysis and correlation coefficients (r) (Zar 1996). Shell size preference data were analyzed using the multiple linear regression: $\ln \mathrm{Y}=a+b \ln \mathrm{X}$, (where $\mathrm{Y}=$ shell measurements: $\mathrm{SAL}=$ shell aperture length; SAW = shell aperture width; SDW = shell dry weight; SIV = shell internal volume, and $\mathrm{X}=$ hermit crab measurements: SL = shield length, and $\mathrm{W}=$ hermit weight).

All shell-species experiments were conducted for the most occupied shell species found in the field [Buccinanops gradatum (Deshayes, 1844), Natica isabelleana Orbigny, 1840 and Olivancillaria urceus (Roding, 1768)] in Brazilian (Martinelli and Mantelatto 1999, Terossi et al. 2006) and in Argentinean waters [Buccinanops gradatum complex shells, i.e., Buccinanops monilifer (Valenciennes, 1834), Buccinanops cochlidium (Chemnitz, 1795), Buccinanops uruguayensis (Pilsbry, 1897), and $N$. isabelleana] (MA Scelzo pers. obs.). 
The experiments were not divided by sex because we assumed that the presence of the three groups (males, non-ovigerous and ovigerous females) in each test would be important to avoid disturbance related to hierarchy behavior. Furthermore, the absence of one or other sexual group could lead the individuals to some behavior different from that observed in nature (Meireles and Mantelatto 2005), where they were found grouped.

Shell-species preference. All experiments were conducted in a pair-wise fashion. In these tests, 15 naked hermit crabs were placed in the aquarium with 150 empty shells of two different species (75 of each species), various and adequate sizes for each locality.

Following $36 \mathrm{~h}$ in this free-choice situation, hermit crabs were removed from their chosen shells, weighed (HW) and measured for SL. Shell species were identified and the SDW, SAW and SIV were determined. Measurements were made with a Vernier caliper $(0.1 \mathrm{~mm})$ or by measuring the drawings of the specimen taken under a light stereomicroscope equipped a camera lucida. Tests were replicated three times. Some voucher hermit crabs were deposited in the Crustacean Collection of the Biology Department of FFCLRP (CCDB), University of São Paulo (catalogue numbers from 1201 to 1204).

Shell-size preference. The experiments were conducted for each of the two shell species separately (Buccinanops gradatum and Olivancillaria urceus). In each test, 15 naked hermit crabs were placed in aquarium with a minimum of 150 empty shells (10 shells/hermit crab) of various and adequate sizes. After 36 $\mathrm{h}$, the hermit crabs were removed from their preferred shells, and both were measured as described above for the shell-species experiments. Each test was repeated three times.

\section{RESULTS}

Shell-species preference. A total of 137 animals were utilized. $P$. exilis showed a significant choice amongst the gastropod shell types. Specimens from Argentina preferred $N$. isabelleana, and those from Brazil chose: $B$. gradatum $>N$. isabelleana $>O$. urceus $(\mathrm{p}<$ 0.01) (Table 1). In general, the morphometric relations that best described the association between Brazilian and Argentinean hermit crabs and their selected shells species were those involving shell dimensions and hermit weight, independent of the shell species (Table 2).

Shell-size preference. During shell-size experiments, a total of 172 animals were utilized. Experiments with specimens from Brazil revealed that the hermit crab's size preference was strongly associated with the shell type. Low correlation coefficients were observed in the less preferred shell type (O. urceus), while in B. gradatum a strong association between hermit crab size and the shell dimensions was found. Experiments with specimens from Argentina revealed a different pattern. In spite of $N$. isabelleana being the most preferred, the correlation coefficients of hermit crabs and B. gradatum to the shell size experiments were higher (Table 3).

TABLE 1

Pagurus exilis. Shell species preference among the shells offered during the experiments

$\begin{array}{ccccc}\text { Study Site } & \text { Species } 1 \text { versus } & \text { Species } 2 & \text { N } & \text { Choice } 1: 2 \\ \text { Brazil } & \text { B. gradatum } & \text { O. urceus } & 45 & 41: 04^{*} \\ \text { Brazil } & \text { B. gradatum } & \text { N. isabelleana } & 30 & 21: 09^{*} \\ \text { Brazil } & \text { N. isabelleana } & \text { O. urceus } & 30 & 30: 00^{*} \\ \text { Argentina } & \text { B. gradatum } & \text { N. isabelleana } & 32 & 07: 25^{*}\end{array}$

ns $=$ not significant, ${ }^{*} \mathrm{p}<0.01$ 
TABLE 2

Pagurus exilis. Regression equations for Brazilian and Argentinean chosen shell species

\begin{tabular}{|c|c|c|c|c|c|c|}
\hline Study site & Chosen shell & $\mathrm{N}$ & Relation & $\begin{array}{l}\text { Linear Equation } \\
\qquad \mathrm{Y}=\mathrm{aX}^{\mathrm{b}}\end{array}$ & $\begin{array}{c}\text { Transformed } \\
\ln y=\ln a+b \ln x\end{array}$ & $\mathrm{r}$ \\
\hline \multirow[t]{16}{*}{ Brazil } & \multirow[t]{8}{*}{ B. gradatum } & 62 & SAW x SL & $\mathrm{SAW}=1.46 \mathrm{SL}^{1.05}$ & $\ln \mathrm{SAW}=0.38+1.05 \ln \mathrm{SL}$ & $0.89 *$ \\
\hline & & 62 & SAL x SL & $\mathrm{SAL}=3.84 \mathrm{SL}^{0.93}$ & $\ln \mathrm{SAL}=1.35+0.93 \ln \mathrm{SL}$ & $0.88^{*}$ \\
\hline & & 62 & SDW x SL & $\mathrm{SDW}=0.04 \mathrm{SL}^{2.40}$ & $\ln \mathrm{SDW}=-3.22+2.40 \ln \mathrm{SL}$ & $0.82^{*}$ \\
\hline & & 62 & SIV x SL & $\mathrm{SIV}=0.01 \mathrm{SL}^{3.20}$ & $\ln \mathrm{SIV}=-4.61+3.20 \ln \mathrm{SL}$ & $0.89 *$ \\
\hline & & 62 & SAW x W & $\mathrm{SAW}=7.87 \mathrm{~W}^{0.31}$ & $\ln \mathrm{SAW}=2.06+0.31 \ln \mathrm{W}$ & $0.92^{*}$ \\
\hline & & 62 & SAL x W & $\mathrm{SAL}=17.10 \mathrm{~W}^{0.27}$ & $\ln \mathrm{SAL}=2.84+0.27 \ln \mathrm{W}$ & $0.91^{*}$ \\
\hline & & 62 & SDW x W & $\mathrm{SDW}=2.05 \mathrm{~W}^{0.72}$ & $\ln \mathrm{SDW}=0.72+0.72 \ln \mathrm{W}$ & $0.85^{*}$ \\
\hline & & 62 & SIV $x$ W & $\mathrm{SIV}=1.85 \mathrm{~W}^{0.93}$ & $\ln \mathrm{SIV}=0.62+0.93 \ln \mathrm{W}$ & $0.91^{*}$ \\
\hline & \multirow[t]{8}{*}{ N. isabelleana } & 39 & SAW x SL & $\mathrm{SAW}=3.03 \mathrm{SL}^{0.69}$ & $\ln \mathrm{SAW}=1.11+0.69 \ln \mathrm{SL}$ & $0.73^{*}$ \\
\hline & & 39 & SAL x SL & $\mathrm{SAL}=5.52 \mathrm{SL}^{0.58}$ & $\ln \mathrm{SAL}=1.71+0.58 \ln \mathrm{SL}$ & $0.71^{*}$ \\
\hline & & 39 & SDW x SL & $\mathrm{SDW}=0.06 \mathrm{SL}^{1.97}$ & $\ln \mathrm{SDW}=-2.81+1.97 \ln \mathrm{SL}$ & $0.69 *$ \\
\hline & & 39 & SIV x SL & $\mathrm{SIV}=0.05 \mathrm{SL}^{2.18}$ & $\ln \mathrm{SIV}=-2.99+2.18 \ln \mathrm{SL}$ & $0.74^{*}$ \\
\hline & & 39 & SAW x W & $\mathrm{SAW}=8.84 \mathrm{~W} \quad 0.25$ & $\ln \mathrm{SAW}=2.18+0.25 \ln \mathrm{W}$ & $0.79 *$ \\
\hline & & 39 & SAL x W & $\mathrm{SAL}=13.60 \mathrm{~W}^{0.21}$ & $\ln \mathrm{SAL}=2.61+0.21 \ln \mathrm{W}$ & $0.79 *$ \\
\hline & & 39 & SDW x W & $\mathrm{SDW}=1.33 \mathrm{~W}^{0.75}$ & $\ln \mathrm{SDW}=0.28+0.75 \ln \mathrm{W}$ & $0.79 *$ \\
\hline & & 39 & SIV $x \mathrm{~W}$ & $\mathrm{SIV}=1.36 \mathrm{~W}^{0.79}$ & $\ln \mathrm{SIV}=0.31+0.79 \ln \mathrm{W}$ & $0.81^{*}$ \\
\hline
\end{tabular}

Argentina $\quad$ B. gradatum $\quad 07$

$\begin{array}{llll}07 & \text { SAL x SL } & \text { SAL }=2.92 \mathrm{SL}^{1.05} \\ 07 & \text { SDW x SL } & \text { SDW }=0.001 \mathrm{SL}^{4.54} \\ 07 & \text { SIV x SL } & \text { SIV }=0.005 \mathrm{SL}^{3.48} \\ 07 & \text { SAW x W } & \text { SAW }=7.91 \mathrm{~W}^{0.34} \\ 07 & \text { SAL x W } & \text { SAL }=16.77 \mathrm{~W}^{0.33} \\ 07 & \text { SDW x W } & \text { SDW }=1.62 \mathrm{~W}^{1.77} \\ \text { N. isabelleana } & 07 & \text { SIV x W } & \text { SIV }=1.77 \mathrm{~W}^{0.93} \\ 25 & \text { SAW x SL } & \text { SAW }=3.09 \mathrm{SL}^{0.66} \\ 25 & \text { SAL x SL } & \text { SAL }=4.72 \mathrm{SL}^{0.67} \\ 25 & \text { SDW x SL } & \text { SDW }=0.01 \mathrm{SL}^{2.91} \\ 25 & \text { SIV x SL } & \text { SIV }=0.03 \mathrm{SL}^{2.44} \\ 25 & \text { SAW x W } & \text { SAW }=8.87 \mathrm{~W}^{0.18} \\ 25 & \text { SAL x W } & \text { SAL }=13.85 \mathrm{~W}^{0.19} \\ 25 & \text { SDW x W } & \text { SDW }=1.38 \mathrm{~W}^{0.85} \\ 25 & \text { SIV x W } & \text { SIV }=1.39 \mathrm{~W}^{0.69}\end{array}$

$\ln \mathrm{SAW}=0.01+1.23 \ln \mathrm{SL} \quad 0.87^{*}$

$\ln \mathrm{SAL}=1.07+1.05 \ln \mathrm{SL} \quad 0.75^{*}$

$\ln \mathrm{SDW}=-7.13+4.54 \ln \mathrm{SL} \quad 0.86^{*}$

$\ln \mathrm{SIV}=-5.30+3.48 \ln \mathrm{SL} \quad 0.88^{*}$

$\ln \mathrm{SAW}=2.07+0.34 \ln \mathrm{W} \quad 0.97 *$

$\ln \mathrm{SAL}=2.82+0.33 \ln \mathrm{W} \quad 0.95 *$

$\ln \mathrm{SDW}=0.48+1.77 \ln \mathrm{W} \quad 0.91 *$

$\ln \mathrm{SIV}=0.57+0.93 \ln \mathrm{W} \quad 0.96 *$

$\ln \mathrm{SAW}=1.13+0.66 \ln \mathrm{SL} \quad 0.71 *$

$\ln \mathrm{SAL}=1.55+0.67 \ln \mathrm{SL} \quad 0.62 *$

$\ln \mathrm{SDW}=-4.61+2.91 \ln \mathrm{SL} \quad 0.73 *$

$\ln \mathrm{SIV}=-3.51+2.44 \ln \mathrm{SL} \quad 0.77 *$

$\ln \mathrm{SAW}=2.18+0.18 \ln \mathrm{W} \quad 0.71 *$

$\ln \mathrm{SAL}=2.63+0.19 \ln \mathrm{W} \quad 0.62 *$

$\ln \mathrm{SDW}=0.32+0.85 \ln \mathrm{W} \quad 0.77 *$

$\ln \mathrm{SIV}=0.33+0.69 \ln \mathrm{W} \quad 0.78^{*}$

$\mathrm{r}=$ correlation coefficient; $\mathrm{SL}$ = shield length; $\mathrm{W}=$ hermit crab weight; SAW = shell aperture width; SAL = shell aperture length; SIV = shell internal volume; SDW = shell dry weight.

* significant correlation, $\mathrm{p}<0.05$ 
TABLE 3

Pagurus exilis. Regression equations for each chosen shell size

\begin{tabular}{|c|c|c|c|c|c|c|}
\hline $\begin{array}{l}\text { Study } \\
\text { Site }\end{array}$ & Species & $\mathrm{N}$ & Relation & $\begin{array}{l}\text { Linear Equation } \\
\qquad \mathrm{Y}=\mathrm{aX}^{\mathrm{b}}\end{array}$ & $\begin{array}{c}\text { Transformed } \\
\text { Lny = lna + blnx }\end{array}$ & r \\
\hline \multirow[t]{27}{*}{ Brazil } & & 42 & SAW x SL & $\mathrm{SAW}=1.65 \mathrm{SL}^{0.93}$ & $\ln \mathrm{SAW}=0.50+0.93 \ln \mathrm{SL}$ & $0.88 *$ \\
\hline & & 42 & SAL x SL & $\mathrm{SAL}=3.63 \mathrm{SL}^{0.93}$ & $\ln \mathrm{SAL}=1.29+0.93 \ln \mathrm{SL}$ & $0.85^{*}$ \\
\hline & & 42 & SDW x SL & $\mathrm{SDW}=0.03 \mathrm{SL}^{2.71}$ & $\ln \mathrm{SDW}=-3.51+2.71 \ln \mathrm{SL}$ & $0.82 *$ \\
\hline & B. gradatum & 41 & SIV x SL & $\mathrm{SIV}=0.01 \mathrm{SL}^{3.12}$ & $\ln \mathrm{SIV}=-4.61+3.12 \ln \mathrm{SL}$ & $0.86^{*}$ \\
\hline & & 42 & SAW x W & $\mathrm{SAW}=7.97 \mathrm{~W}^{0.26}$ & $\ln \mathrm{SAW}=2.08+0.26 \ln \mathrm{W}$ & $0.85 *$ \\
\hline & & 42 & SAL $x \mathrm{~W}$ & $\mathrm{SAL}=18.04 \mathrm{~W}^{0.29}$ & $\ln \mathrm{SAL}=2.89+0.29 \ln \mathrm{W}$ & $0.91 *$ \\
\hline & & 42 & SDW x W & $\mathrm{SDW}=2.56 \mathrm{~W}^{0.74}$ & $\ln \mathrm{SDW}=0.94+0.74 \ln \mathrm{W}$ & $0.77^{*}$ \\
\hline & & 41 & SIV x W & $\mathrm{SIV}=2.06 \mathrm{~W}^{0.93}$ & $\ln \mathrm{SIV}=0.72+0.93 \ln \mathrm{W}$ & $0.89 *$ \\
\hline & & 28 & SAW x SL & $\mathrm{SAW}=2.47 \mathrm{SL}^{0.79}$ & $\ln \mathrm{SAW}=0.90+0.79 \ln \mathrm{SL}$ & $0.69 *$ \\
\hline & & 28 & SAL x SL & $\mathrm{SAL}=5.42 \mathrm{SL}^{0.59}$ & $\ln \mathrm{SAL}=1.69+0.59 \ln \mathrm{SL}$ & $0.57 *$ \\
\hline & & 28 & SDW x SL & $\mathrm{SDW}=0.05 \mathrm{SL}^{2.10}$ & $\ln \mathrm{SDW}=-2.99+2.10 \ln \mathrm{SL}$ & $0.57 *$ \\
\hline & N. isabelleana & 28 & SIV x SL & $\mathrm{SIV}=0.06 \mathrm{SL}^{1.96}$ & $\ln \mathrm{SIV}=-2.81+1.96 \ln \mathrm{SL}$ & $0.66^{*}$ \\
\hline & & 28 & SAW x W & $\mathrm{SAW}=9.00 \mathrm{~W}^{0.23}$ & $\ln \mathrm{SAW}=2.20+0.23 \ln \mathrm{W}$ & $0.78 *$ \\
\hline & & 28 & SAL x W & $\mathrm{SAL}=14.17 \mathrm{~W}^{0.20}$ & $\ln \mathrm{SAL}=2.65+0.20 \ln \mathrm{W}$ & $0.73^{*}$ \\
\hline & & 28 & SDW x W & $\mathrm{SDW}=1.48 \mathrm{~W}^{0.67}$ & $\ln \mathrm{SDW}=0.39+0.67 \ln \mathrm{W}$ & $0.71 *$ \\
\hline & & 28 & SIV $x$ W & $\mathrm{SIV}=1.59 \mathrm{~W}^{0.60}$ & $\ln \mathrm{SIV}=0.46+0.60 \ln \mathrm{W}$ & $0.79 *$ \\
\hline & & 39 & SAW x SL & $\mathrm{SAW}=8.03 \mathrm{SL}^{-0.07}$ & $\ln \mathrm{SAW}=2.08-0.07 \ln \mathrm{SL}$ & $0.05^{\text {ns }}$ \\
\hline & & 39 & SAL x SL & $\mathrm{SAL}=27.19 \mathrm{SL}^{-0.13}$ & $\ln \mathrm{SAL}=3.30-0.13 \ln \mathrm{SL}$ & $0.10^{\mathrm{ns}}$ \\
\hline & & 39 & SDW x SL & $\mathrm{SDW}=17.38 \mathrm{SL}^{-0.69}$ & $\ln \mathrm{SDW}=2.86-0.69 \ln \mathrm{SL}$ & $0.14^{\mathrm{ns}}$ \\
\hline & O. urceus & 39 & SIV $x$ SL & $\mathrm{SIV}=1.66 \mathrm{SL}^{0.08}$ & $\ln \mathrm{SIV}=0.51+0.08 \ln \mathrm{SL}$ & $0.02^{\text {ns }}$ \\
\hline & & 39 & SAW x W & $\mathrm{SAW}=7.25 \mathrm{~W}^{0.05}$ & $\ln \mathrm{SAW}=1.98+0.05 \ln \mathrm{W}$ & $0.11^{\mathrm{ns}}$ \\
\hline & & 39 & SAL $x \mathrm{~W}$ & $\mathrm{SAL}=22.34 \mathrm{~W}^{0.04}$ & $\ln \mathrm{SAL}=3.11+0.04 \ln \mathrm{W}$ & $0.10^{\mathrm{ns}}$ \\
\hline & & 39 & SDW x W & $\mathrm{SDW}=5.95 \mathrm{~W}^{0.08}$ & $\ln \mathrm{SDW}=1.78+0.08 \ln \mathrm{W}$ & $0.06^{\mathrm{ns}}$ \\
\hline & & 39 & SIV $x$ W & $\mathrm{SIV}=1.93 \mathrm{~W}^{0.17}$ & $\ln \mathrm{SIV}=0.66+0.17 \ln \mathrm{W}$ & $0.14^{\mathrm{ns}}$ \\
\hline & & 30 & SAW x SL & $\mathrm{SAW}=2.28 \mathrm{SL}^{0.81}$ & $\ln \mathrm{SAW}=0.82+0.81 \ln \mathrm{SL}$ & $0.68 *$ \\
\hline & & 30 & SAL x SL & $\mathrm{SAL}=4.81 \mathrm{SL}^{0.79}$ & $\ln \mathrm{SAL}=1.57+0.79 \ln \mathrm{SL}$ & $0.69 *$ \\
\hline & & 30 & SDW x SL & $\mathrm{SDW}=0.10 \mathrm{SL}^{1.95}$ & $\ln \mathrm{SDW}=-2.30+1.95 \ln \mathrm{SL}$ & $0.62 *$ \\
\hline \multirow[t]{13}{*}{ Argentina } & B. gradatum & 30 & SIV x SL & $\mathrm{SIV}=0.09 \mathrm{SL}^{1.90}$ & $\ln \mathrm{SIV}=-2.41+1.90 \ln \mathrm{SL}$ & $0.69 *$ \\
\hline & & 30 & SAW x W & $\mathrm{SAW}=7.98 \mathrm{~W}^{0.30}$ & $\ln \mathrm{SAW}=2.08+0.30 \ln \mathrm{W}$ & $0.74^{*}$ \\
\hline & & 30 & SAL $x \mathrm{~W}$ & $\mathrm{SAL}=16.12 \mathrm{~W}^{0.30}$ & $\ln \mathrm{SAL}=2.78+0.30 \ln \mathrm{W}$ & $0.79 *$ \\
\hline & & 30 & SDW x W & $\mathrm{SDW}=2.11 \mathrm{~W}^{0.68}$ & $\ln \mathrm{SDW}=0.75+0.68 \ln \mathrm{W}$ & $0.65 *$ \\
\hline & & 30 & SIV $x$ W & $\mathrm{SIV}=1.79 \mathrm{~W}^{0.68}$ & $\ln \mathrm{SIV}=0.58+0.68 \ln \mathrm{W}$ & $0.74 *$ \\
\hline & & 33 & SAW x SL & $\mathrm{SAW}=4.20 \mathrm{SL}^{0.74}$ & $\ln \mathrm{SAW}=1.44+0.74 \ln \mathrm{SL}$ & $0.56^{*}$ \\
\hline & & 33 & SAL x SL & $\mathrm{SAL}=2.74 \mathrm{SL}^{0.69}$ & $\ln \mathrm{SAL}=1.01+0.69 \ln \mathrm{SL}$ & $0.56^{*}$ \\
\hline & & 33 & SDW x SL & $\mathrm{SDW}=0.22 \mathrm{SL}^{1.35}$ & $\ln \mathrm{SDW}=-1.51+1.35 \ln \mathrm{SL}$ & $0.33^{\text {ns }}$ \\
\hline & N. isabelleana & 33 & SIV x SL & $\mathrm{SIV}=0.03 \mathrm{SL}^{2.37}$ & $\ln \mathrm{SIV}=-3.51+1.37 \ln \mathrm{SL}$ & $0.61 *$ \\
\hline & & 33 & SAW $x$ W & $\mathrm{SAW}=13.28 \mathrm{~W}^{0.23}$ & $\ln \mathrm{SAW}=2.59+0.23 \ln \mathrm{W}$ & $0.57 *$ \\
\hline & & 33 & SAL x W & $\mathrm{SAL}=7.94 \mathrm{~W}^{0.22}$ & $\ln \mathrm{SAL}=2.07+0.22 \ln \mathrm{W}$ & $0.59 *$ \\
\hline & & 33 & SDW x W & $\mathrm{SDW}=1.87 \mathrm{~W}^{0.27}$ & $\ln \mathrm{SDW}=0.62+0.27 \ln \mathrm{W}$ & $0.22^{\text {ns }}$ \\
\hline & & 33 & SIV x W & $\mathrm{SIV}=1.31 \mathrm{~W}^{0.66}$ & $\ln \mathrm{SIV}=0.27+0.66 \ln \mathrm{W}$ & $0.57 *$ \\
\hline
\end{tabular}

$\mathrm{r}=$ correlation coefficient; SL = shield length; $\mathrm{W}$ = hermit crab weight; SAW = shell aperture width; SAL = shell aperture length; SDW = shell dry weight; SIV = shell internal volume.

* significant correlation, $\mathrm{p}<0.05$; ns = not significant 


\section{DISCUSSION}

Recent investigations with molecular analysis by $16 \mathrm{~S}$ mtDNA made by one of us (FL Mantelatto) have showed that no marked genetic variability occurs among southern populations of $P$. exilis from both regions (Brazil and Argentina) in the southwestern Atlantic. Therefore, the general results were not influenced by genetic variability. Despite of this, some preliminary results have detected ecological differences in distribution and size of specimens between the above mentioned populations (FL Mantelatto and MA Scelzo, unpubl. data). The need to explain this evolutionary relationship certainly inspired the present study.

Animals often must compromise among different sets of demands when selecting resources (Yoshino et al. 1999). Hermit crabs do not necessarily live in shells they prefer, and the availability of different shell types and contact with competitors for empty shells influences shell occupation (Bertness 1980). $P$. exilis showed significant choices amongst the gastropod shell species in the two studied regions. Specimens from Brazil preferred $B$. gradatum over $N$. isabelleana and $O$. urceus shells, while those from Argentina preferred $N$. isabelleana over B. gradatum. Considering that in the Ubatuba region $O$. urceus is one of the most available shells (AL Meireles pers. obs.) and it is also occupied by other hermit species, its availability to $P$. exilis not necessarily determines this shell species occupation. In Argentina, there is a lack of studies on gastropod availability but according to Scelzo et al. (2004), Buccinanops shells are the most occupied by $P$. exilis in the field followed by Natica.

Previous studies conducted by Abrams (1978), Elwood et al. (1979), Siu and Lee (1992), Ohmori et al. (1995), Hahn (1998), Dominciano and Mantelatto (2004), Biagi et al. (2006) found that the hermit crabs in the laboratory preferred those shell species most occupied in the field. A similar pattern of shell selection also was found in the present study.
However, the absence of a shell species preference under laboratory conditions was found by Orians and King (1964) for Pagurus samuelis (Stimpson, 1857) and Pagurus granosimanus (Stimpson, 1858), by Siu and Lee (1992) for Clibanarius bimaculatus (De Haan, 1854), by Garcia and Mantelatto (2001) for Calcinus tibicen (Herbst, 1791) and by Meireles and Mantelatto (2005) for Pagurus brevidactylus (Stimpson, 1859).

The shell size experiments revealed that O. urceus shells provided a low specimen adequacy to $P$. exilis. This fact, associated with the preference for B. gradatum in Brazil, suggested that $O$. urceus shells are the morphometrically less adequate within the most occupied shell species in the field (Terossi et al. 2006). According to Yoshino et al. (1999), there is a trade-off between shell size and species preference, and that less preferred shell species are actively chosen when the more preferred shell species the crabs encounter frequently in the field are of a less suitable size. Considering the great availability (in size and number) of $O$. urceus shells in the field (AL Meireles pers. obs.), we may infer that the assertion proposed by Yoshino et al. (1999) may not be applied to $P$. exilis and that it may not have exhibited preference for $O$. urceus because of its higher weight when compared to the other shells.

Specimens from Argentina demonstrated no particular preference among the shell dimensions studied. However, higher correlation coefficients were obtained for Buccinanops complex shells despite the fact that $N$. isabelleana were the most preferred in the shell type experiments. In contrast, $P$. exilis showed different patterns of occupation in the field observations carried out in Argentina, where Buccinanops gradatum complex species were the most occupied shells (66 \%) compared with $N$. isabelleana (19 \%) (Scelzo et al. 2004). As demonstrated for Loxopagurus loxochelis (Moreira, 1901) by Biagi et al. (2006), populations of the same species inhabiting different and distant areas may present distinct shell selection behaviors. $P$. exilis specimens from Argentina presented no 
preference among the tested shells under laboratory conditions; in contrast, Brazilian ones preferred one shell instead of the other tested. Furthermore, according to the latter authors this discrepancy is a function of the hermit crab species, the origin of the population as well as the availability of the resources in the area of occurrence.

In the present investigation, $P$. exilis from different areas exhibited different preferences among shell species which lead us to conclude that some particular differences in shell preferences may be attributed both to the morphology of hermit crabs and to environmental conditions, with the animals looking for protection against the factors to which they are exposed (predation, energy expenditure, osmotic stress and wave action) (Garcia and Mantelatto 2001).

The $P$. exilis populations from Brazil and Argentina present differences in the mean size of the specimens, with Argentinean hermit crabs reaching larger sizes $(5.46 \pm 0.59 \mathrm{~mm} \mathrm{SL})$ than the Brazilian ones $(5.01 \pm 0.86 \mathrm{~mm} \mathrm{SL})$. This pattern is in accordance with the one proposed by Abele (1982), who postulated that the size of crustaceans decreases with decreasing latitude. Furthermore, according to Ohmori et al. (1995) shell utilization patterns would change with different crab sizes, even within the same species. This might explain the differences found in the patterns of shell species preference between both hermit crabs populations.

We are in agreement with Lancaster (1988) that "hermit crabs are particularly good at solving the problems of limited resources and are efficient at both exploiting what they have and contesting what they have not".

In the present study, $P$. exilis preferred lighter shells that promote less protection but with greater internal volume (B. gradatum and $N$. isabelleana). We believe that this preference is strongly related to energy savings where males would invest in fast growth as they can enjoy high levels of mating when occupying adequate shells (Harvey 1990) and females in reproductive activities. Also, considering the high mobility and fragile body structure exhibited by $P$. exilis and its great abundance (the second most abundant species) in the nonconsolidate infralittoral area in São Paulo coast (Meireles et al. in press), it would be expected that the occupation of a shell would facilitate its behavior the occupation of a shell that would facilitate its behavior and guarantee survivorship. However, further studies on reproductive and growth aspects may contribute to a better understanding of the role of the shell utilization in the population dynamics of $P$. exilis along the western Atlantic as well as the relationship of shell occupation in relation to the coexistent species $L$. loxochelis.

\section{ACKNOWLEDGMENTS}

The major funding for this project was provided by a grant to FLM by Conselho Nacional de Desenvolvimento Científico e Tecnológico (CNPq) during the International Cooperative Project - CNPq - Prosul Program (Grants 170038/02-5; 490340/2004-0 and 490122/06-0) that provided financial support to FLM and MAS during Brazil and Argentina visiting program. ALM and RB are indebted to Fundação de Amparo à Pesquisa do Estado de São Paulo (FAPESP) for Doctoral fellowships. RB and FLM are also grateful to CNPq for Post Doctoral and for Research on-going fellowships, respectively. MAS is grateful to UNMDP (EXA 280/04 y 15/E226) and CONICET (Argentina) for partial support. Special thanks to those who collaborated with this study, especially Adilson Fransozo (Paulista State University) and many colleagues from the NEBECC who helped with sampling, and Post-Graduation Course in Comparative Biology of FFCLRP/USP for assistance. Our gratitude to three anonymous reviewers for valuable suggestions on an earlier version of this manuscript.

\section{RESUMEN}

Las preferencias por conchas de caracoles gastrópodos en los cangrejos ermitaños, según han demostrado experimentos de selección en el laboratorio, son importantes para 
definir la utilización de conchas en condiciones naturales. Comparamos el tamaño y la especie de conchas preferidas por el cangrejo ermitaño Pagurus exilis con las especies más ocupadas (Olivancillaria urceus, Natica isabelleana y Buccinanops gradatum) en la región de Caraguatatuba, Brasil, y para las dos más ocupadas ( $B$. gradatum y N. isabelleana) en Mar del Plata, Argentina. Todos los experimentos fueron hechos en acuarios de vidrio donde los cangrejos ermitaños fueron puestos sin sus conchas, ofreciéndoles conchas de tamaños apropiados. Luego de $36 \mathrm{~h}$ medimos los cangrejos y las conchas seleccionadas. La relación entre el tipo de concha preferida, el tamaño y el volumen, se analizó con análisis de regresión. $P$. exilis mostró una selección significativa. Los especimenes de Argentina prefirieron $N$. isabelleana y los de Brasil eligieron B. gradatum $>N$. isabelleana $>O$. urceus. La preferencia estuvo caracterizada por el peso de la concha y su volumen interno. Los datos actuales nos llevan a concluir que la selección de la concha involucra preferencias individuales, que tienen en cuenta los rasgos de las conchas que proveen mejor protección y supervivencia.

Palabras clave: Crustacea, Paguridae, Pagurus exilis, ocupación de concha, Atlántico sudoccidental.

\section{REFERENCES}

Abele, L.G. 1982. Biogeography. p. 242-292 In D.E. Bliss (ed.). The Biology of Crustacea. Systematics, the Fossil Record, and Biogeography. Vol. 1, Academic, London, England.

Abrams, P.A. 1978. Shell selection and utilization in a terrestrial hermit crab, Coenobita compressus (H. Milne Edwards). Oecologia 34: 239-253.

Bertness, M.D. 1980. Shell preference and utilization patterns in littoral hermit crabs of the Bay of Panama. J. Exp. Mar. Biol. Ecol. 48: 1-16.

Bertness, M.D. 1981. The influence of shell-type on hermit crab growth rate and clutch size. Crustaceana 40: 197-205.

Biagi, R., Meireles, A.L., Scelzo, M.A. \& F.L. Mantelatto. 2006. Comparative study of shell choice by the southern endemic hermit crab Loxopagurus loxochelis from Brazil and Argentina. Rev. Chil. Hist. Nat. 79:481-487.

Blackstone, N.W. 1985. The effects of shell size and shape on growth and form in the hermit crab Pagurus longicarpus. Biol. Bull. 168: 75-90.
Conover, M. 1978. The importance of various shell characteristics to the shell-selection behavior of the hermit crabs. J. Exp. Mar. Biol. Ecol. 32: 131-142.

Dominciano, L.C.C. \& F.L. Mantelatto. 2004. The influence of shell species and size on the shell selection pattern of Paguristes tortugae (Decapoda, Diogenidae) from Anchieta Island (Ubatuba, Brazil). Iheringia, Ser. Zool. 94: 425-428.

Elwood, R.W., McLean, A. \& L. Webb. 1979. The development of shell preferences by the hermit crab Pagurus bernhardus. Anim. Behav. 27: 940-946.

Garcia, R.B. \& F.L. Mantelatto. 2001. Shell selection by the tropical hermit crab Calcinus tibicen (Herbst, 1791) (Anomura, Diogenidae) from southern Brazil. J. Exp. Mar. Biol. Ecol. 265: 1-14.

Goshima, S., H. Ohmori \& S. Wada. 1996. Reproductive biology of the hermit crab Pagurus nigrofascia (Anomura, Paguridae). Crust. Res. 25: 86-92.

Hahn, D.R. 1998. Hermit crab shell use patterns: response to previous shell experience and to water flow. J. Exp. Mar. Biol. Ecol. 228: 35-51.

Harvey, A.W. 1990. Sexual differences in contemporary selection acting on size in the hermit crab Clibanarius digueti. Amer. Nat. 136: 292-304.

Hazlett, B.A. 1992. The effect of past experience on the size of shells selected by hermit crabs. Anim. Behav. 44: 203-205.

Hazlett, B.A. 1996. Recent experience and the shellsize preference of hermit crabs. Mar. Fresh. Behav. Physiol. 28: 177-182.

Hendrickx, M.E. \& A. Harvey. 1999. Checklist of anomuran crabs (Crustacea, Decapoda) from the eastern tropical Pacific. Belg. J. Zool. 129: 363-389.

Lancaster, I. 1988. Pagurus bernhardus (L.)-An introduction to the natural history of hermit crabs. Field Stud. 7: 189-238.

Lemaitre, R. \& N. Cruz Castaño. 2004. A new species of Pagurus Fabricius, 1775 from the Pacific coast of Colombia, with a checklist of eastern Pacific species of the genus. Nauplius 12: 71-82.

Lively, C.M. 1988. A graphical model for shell-species selection by hermit crabs. Ecology 69: 1233-1238. 
Mantelatto, F.L. \& L.C.C. Dominciano. 2002. Pattern of shell utilization by the hermit crab Paguristes tortugae (Diogenidae) from Anchieta Island, southern Brazil. Sci. Mar. 66: 265-272.

Mantelatto, F.L. \& A.L. Meireles. 2004. The importance of shell occupation and shell availability in the hermit crab Pagurus brevidactylus (Stimpson, 1859) (Paguridae) population from the southern Atlantic. Bull. Mar. Sci. 75: 27-35.

Mantelatto, F.L., Espósito, D.L.A., M. Terossi, R. Biagi \& A.L. Meireles. In press. Population features of the western Atlantic hermit crab Pagurus exilis (Anomura, Paguridae) in Brazil. Atlântica.

Martinelli, J.M. \& F.L. Mantelatto. 1999. Shell utilization by the hermit crab Loxopagurus loxochelis (Diogenidae) in Ubatuba Bay, Brazil. p. 719-731. In F.R. Schram \& J.C. Vaupel Klein (eds.). Crustaceans and the Biodiversity Crisis. Brill, Leiden, The Netherlands.

Meireles, A.L. \& F.L. Mantelatto. 2005. Shell use by Pagurus brevidactylus (Anomura, Paguridae): a comparison between laboratory and field conditions. Acta Zool. Sinica 51: 813-820.

Meireles, A.L., R. Biagi, A. Fransozo \& F.L. Mantelatto. In press. Os Ermitões (Crustacea, Anomura). In A.C.Z. Amaral \& S.A.H. Nallin (eds). Biodiversidade e Ecossistemas Bentônicos Marinhos do Litoral Norte de São Paulo - Sudeste do Brasil. Universidade Estadual de Campinas, São Paulo, Brazil.

Melo, G.A.S. 1999. Manual de identificação dos Crustacea Decapoda do litoral brasileiro: Anomura, Thalassinidea, Palinuridea, Astacidea. Plêiade, São Paulo, Brazil. 551 p.

Ohmori, H., S. Wada, S. Goshima \& S. Nakao. 1995. Effects of body size and shell availability on the shell utilization pattern of the hermit crab Pagurus filholi (Anomura: Paguridae). Crust. Res. 24: 85-92.

Orians, G.H. \& C.E. King. 1964. Shell selection and invasion rates of some Pacific hermit crabs. Pac. Sci. 18: 297-306.

Reese, E.S. 1962. Shell selection behaviour of hermit crabs. Anim. Behav. 10: 347-360.
Rodrigues, L.J., D.W. Dunham \& K.A. Coates. 2000. Shelter preferences in the endemic bermudian hermit crab Calcinus verrilli (Rathbun, 1901) (Decapoda, Anomura). Crustaceana 73: 737-750.

Scelzo, M.A. \& E.E. Boschi. 1969. Desarollo larval del cangrejo ermitaño Pagurus exilis (Benedict) en laboratorio (Crustacea, Anomura, Paguridae). Physis 29: 165-184.

Scelzo, M.A., D. Luzatto, M. Flaminio \& J. Martínez Arca. 2004. Pattern of shell utilization by the hermit crab Pagurus exilis (Benedict) (Decapoda: Anomura: Paguridae) in the area of Mar del Plata-Mar Chiquita, Buenos Aires, Argentina. p. 85. In F.L. Mantelatto, A.L. Meireles \& R. Biagi. (eds.). Book of Abstracts of the $3^{\text {rd }}$ Brazilian Crustacean Congress and The Crustacean Society Meeting, Florianópolis, Brazil.

Siu, B.F.C. \& S.Y. Lee. 1992. Shell preference and utilization pattern in two hermit crabs, Pagurus trigonocheirus (Stimpson) and Clibanarius bimaculatus (De Haan), on a sheltered rocky shore in Hong Kong. Asian Mar. Biol. 9: 205-216.

Terossi, M., D.L.A. Espósito, A.L. Meireles, R. Biagi \& F.L. Mantelatto. 2006. Pattern of shell occupation by the hermit crab Pagurus exilis (Anomura, Paguridae) on the northern coast of São Paulo State, Brazil. J. Nat. Hist. 40: 77-87.

Vance, R.R. 1972. The role of shell adequacy in behavioral interactions involving hermit crabs. Ecology 53: $1075-1083$.

Wada, S., H. Ohmori, S. Goshima \& S. Nakao. 1997. Shell size preference of hermit crabs depends on their growth rate. Anim. Behav. 54: 1-8.

Wilber, Jr., T.P. 1990. Influence of size, species and damage on shell selection by the hermit crab Pagurus longicarpus. Mar. Biol. 104: 31-39.

Yoshino, K., S. Goshima \& S. Nakao. 1999. The interaction between shell size and shell species preferences of the hermit crab Pagurus filholi. Benthos Res. 54: 37-44.

Zar, J.H. 1996. Biostatistical Analysis. Prentice-Hall. New Jersey, USA. 662 p. 
